and in medicine, and in the humanities high scholarship was stimulated. In making new appointments, although he insisted on high professional qualifications, he sought also men of character and culture, believing, to quote his own words, that "no teachers can conceal their characters and outlook on life from a class".

Unbending as granite where ethical principles were concerned, Wallace listened gladly to views opposed to his own and was kind to people in all walks of life. His office door was open, literally and metaphorically, to members of staff and students alike. Like most Scots, he made no outward display of the sentiment which lay below the surface. But only a few months before his death, on the occasion of the centenary of The Orcadian, he wrote with feeling of "scenes of cliff and sea and sky" and of "that indescribably soft ethereal light at or near midnight on summer's longest days in the Orkneys", things which were caught "indelibly in memory".

$\mathrm{He}$ is survived by his wife, Elizabeth Smith, also a native of the Orkneys, whose graciousness and natural charm added greatly to the warm welcome given the many who went to the principal's residence on Queen's University grounds. Three deughters, Mrs. D. E. Woodsworth, Mrs. H. W. Addington and Mrs. Charles Baugh, also survive. A son, Ronald, died in 1936 .

J. K. ROBERTSON

\section{Mr. G. W. Grabham, O.B.E.}

George Walter Grabham was born in 1882 in Madeira, where his father, Dr. Michael Grabham, was a well-known resident. Educated at University College School and at St. John's College, Cambridge, he joined the Geological Survey of Great Britain in 1903 and worked in Scotland until 1906. He then followed T. Barron as Government geologist in the Anglo-Egyptian Sudan. There, throughout his service, he travelled widely, on foot and by river, with camels and with both early and modern motor transport. He was mainly concerned with the most vital need-water; and in his journeys and special investigations $\mathrm{h} \theta$ gathered a unique knowledge of the geology of the country. By far the greater part of his work is represented by unpublished reports in the Geological Survey office in Khartoum. He was also closely interested in the people's agricultural and other pursuits, past and present, and was acting conservator of antiquities.

Outside the Sudan he made extensive journeys, about which little was heard, in inter-tropical Africa; he was best known for his official mission to Lake Tana (with R. P. Black, 1920-21).

Grabham retired from the Geological Survey of the Sudan in 1934, but was retained as geological adviser until 1939. After the Second World War he wintered in the Sudan, maintaining vigorously his many and varied personal interests.

In Madeira he inherited his father's house, where his affection for the island, and all that it implied for him, was widely known. To the end he made exacting walks in that land of profound cliffs and gorges. Here, as in the Sudan, he took unflagging pleasure in showing others the country, either on the ground or with the aid of his vast collection of photographs and lantern slides; his hospitality was proverbial.

$\mathrm{He}$ was a familiar figure at international geological congresses, and on their long field excursions, in many parts of the world, and for many years his annual visit to Britain coincided with the meeting of the British Association, at which he enjoyed meeting his friends; latterly he came to his clubs in London twice a year, and made a tour of his diminishing circle of relatives and close associates.

To many, Grabham seemed a lonely man, but he delighted in company; a rather forbidding figure, but he had an inexhaustible fund of humour; of his sympathy and kindness the sum will never be told. His end was as he would probably have wished; he was about to lecture to a cultural meeting in Khartoum, but, feeling unwell, took his leave and bicycled home to his house in Burri Village, where he was found dead the following morning. So passes a great figure.

K. S. SANDFORD

\section{Dr. W. M. Ware}

Former colleagues have experienced a deep sense of loss following the sudden death, on February 15, of William Melville Ware at the age of sixty-two. Particularly has the loss been felt by many present and past members of Wye College (University of London), for it was there that all his scientific work was done.

Ware entered Wye College in 1911 as a student, after receiving a grounding in the classics at Dover College, followed by a period in an academy at Le Havre, where he attained fluency in French. During the First World War he was on active service with the Army and on demobilization returned to Wye as a lecturer in botany. Research, however, was his métier ; while still a lecturer he investigated problems of clover with a grant from the Ministry of Agriculture, and this led to the publication of several papers on the subject and on certain diseases of other plants.

In 1923 he accepted an invitation to join the Mycology Department (Research and Advisory) under the direction of Prof. E. S. Salmon. For the next twenty-three years his investigations formed a major stimulus to the growth of the young science of plant pathology.

His main researches were on diseases of fruit, hops and mushrooms; but other horticultural and agricultural crops also received attention, and about a hundred original papers of high quality appeared under his name, either alone or jointly with colleagues. His researches into apple scab (Venturia inaequalis (Cooke) Wint.) and hop downy mildew (Pseudoperonospora humuli (Miyabe and Tak) G. W. Wilson) are particularly outstanding, while his observations on the cultivated mushroom led not only to the discovery of crop-reducing diseases, but also to the writing of a bulletin on mushroom-growing for the Ministry of Agriculture. Following his first degree of B.Sc. (Agric.), he was awarded the M.Sc. in 1923 and the D.Sc. in 1935.

Ware followed Prof. Salmon as head of the Mycology Department at Wye in 1937, and directed research and advisory work through the difficult war years; but the decision to absorb the Department into the Civil Service prompted his retirement in October 1946.

Ware served on the Council of the Association of Applied Biologists and as a member of the Plant Pathology Committee of the British Mycological Society; but his distaste for committee work debarred him from seeking office in the learned societies. His contributions to science are familiar to 
plant pathologists throughout the world and, had his ambition equalled his ability, high academic rewards would undoubtedly have been his.

In retirement, gardening and travel were among his chief delights; but since 1948, as assistant editor of the Journal of Horticultural Science, he had kept in touch with current research.
Although modest and reserved to an unusual degree, Ware's attractive personality brought him a wide circle of friends, and many of those who knew him best have reason to be grateful for his help and for his counsel, which was sought by his seniors as well as by his juniors. He leaves a widow.

H. H. Grasscock
Research in the Physics of Solids:

\section{NEWS and VIEWS}

\author{
Prof. A. H. Cottrell
}

Prof. A. H. CotTrell, of the Department of Physical Metallurgy, University of Birmingham, has accepted an appointment with the U.K. Atomic Energy Authority, at the Atomic Energy Research Establishment, Harwell, as deputy head of the Metallurgy Division and leader of a group engaged in research on the physies of solids. He will be taking up his new appointment in April. Prof. Cottrell, who is thirty-five, is a graduate of the University of Birmingham. During 1939-45 he was engaged in research on the welding of tank armour. He was appointed a lecturer in motallurgy in the University of Birmingham in 1943. When the late Prof. Hanson, immediately after the War, was re-organizing teaching and research in metallurgy at Birmingham, one of his principal objects was to create a strong school of theoretical and physical metallurgy. The Department of Scientific and Industrial Research gave substantial support for an initial period, and with notable vision Prof. Hanson recommended the University to create two new professorships, one in physical metallurgy and the other in metal physics. Accordingly, in 1949 Dr. Cottrell and Dr. G. V. Raynor, then reader in theoretical metallurgy, were appointed to the new chairs. On the death of Prof. Hanson in 1953, Profs. Cottrell and Raynor were made joint heads of the Department of Physical Metallurgy.

Prof. Cottrell's researches have been mainly concerned with the plastic deformation of metal crystals. In ample justification of Prof. Hanson's hopes, he and the group of able young men whom he has gathered around him have done much to establish Britain's leading position in this field of research. Prof. Cottrell has travelled extensivelyhe made lecture tours in the United States in 1950 and 1953 and was guest lecturer at the University of the Witwatersrand in 1952 and at the University of Louvain in 1953. He attended the Ninth International Solvay Conference on Physics at Brussels in 1951, and delivered the 1953 R. S. Williams Lectures at the Massachusetts. Institute of Technology. $\mathrm{He}$ was awarded the Rosenhain Medal by the Institute of Metals in 1954. Prof. Cottrell has acted as chairman. of the Basic .Properties Committee. of the InterService Metallurgical Research Council, and is also associate editor for Great Britain of Acta Metallurgica.

\section{Psychology at Glasgow :}

Prof. R. W. Pickford

Prof. Ralph WILLIam PICKrord, who has been appointed to be the first incumbent of the recently created chair of psychology in the University of Glasgow, has been associated with the Department of Psychology at Glasgow for more than twenty-five years. His first appointment there was in 1930 as assistant to Dr. R. H. Thouless, becoming lecturer in 1935 and senior lecturer and head of the Depart- ment in 1948. Dr. Pickford was a student at the then Southampton University College before proceeding in 1923 to Emmanuel College, Cambridge, where he graduated in psychology and obtained his Ph.D. in 1932. During 1927-32, with a grant from the Vision Committee of the Medical Research Council, Prof. Pickford undertook research on the psychology of reading. His publications include a monograph, two books, and many papers and articles dealing especially with experimental studies of colour vision and visual perception, and with the psychology of art and social and clinical psychology. $\mathrm{He}$ has been president and is retiring secretary of the Scottish Branch of the British Psychological Society, and was a founder member and the first president of the Experimental Psychology Group. For ten years he has worked in a voluntary capacity at the Notre Dame Child Guidance Clinic, at the Davidson Clinic, Glasgow, and as a counsellor for the Glasgow Marriage Guidance Council. He is keenly interested in music.

\section{Sir George Beilby Memorial Awards, 1954}

THe administrators of the Sir George Beilby Memorial Fund, representing the Institute of Metals, the Royal Institute of Chemistry and the Society of Chemical Industry, have made awards from the Fund for 1954, each of one hundred and fifty guineas, to Dr. H. K. Hardy and to Dr. J. W. Menter. The awards are made to British investigators for work in such fields as fuel economy, chemical engineering and metallurgy, in which Sir George Beilby's special interests lay, and in general they are given to relatively young scientists for work over a period of years.

Dr. H. K. Hardy's award is for work in physical metallurgy, with special reference to precipitation hardening and to the thermodynamics of phase equilibria in alloy systems. He graduated in metallurgy from the Imperial College of Science and Technology, London, in 1940, and afterwards, while at the Research Department of the Northerm Aluminium Co., Ltd., and at Aluminium Laboratories, Ltd., he was concerned with the metallography of duralumin-type alloys and the development of high-strength aluminium-zinc-magnesium alloys, particularly the nature of the extrusion process and the microstructural effects associated with the onset of overheating. In 1946 he joined the Fulmer Research Institute as head of the Physical Metallurgy Section and later as senior metallurgist, where he investigated the precipitation process in aluminiumcopper alloys over a wide range of supersaturations and with the addition of small quantities of other elements. The thermodynamics of this and other phase equilibria in alloy systems have been closely studied.

Dr. J. W. Menter entered Peterhouse, Cambridge, and after governmental war-time service graduated in physics in 1945. His Beilby award is for work on surface phenomena, with special reference to the 